truly have been a role model for me." For her students, their Professor Lansing had been there and done it in the trenches of political life- unlike our armchair philosophers and cafe intellectuals. She linked these experiences to the world of research, and she projected them with her boundless energy to make scholarship meaningful in ways that students understood and appreciated.

Robert C. Grady

David W. Hortin

Eastern Michigan University

\section{Myres Smith McDougal}

Myres Smith McDougal, Sterling

Professor Emeritus of Law at Yale University, died on May 7, after a long illness. He was 92 years old.

A renowned authority on international law, Professor McDougal founded, along with political scientist Harold D. Lasswell, the New Haven School of Jurisprudence, a policyscience approach to the study of law that conceives of law not as a body of rules, but as a process of decision.

Professor McDougal called his jurisprudence "configurative" and "policy-oriented." In his view, the challenge was to develop and apply an approach to the study and practice of law so that law could contribute to the achievement of a public order respectful of human dignity.

Aside from his prominence as a legal scholar, Professor McDougal, known as "Mac" to his students and colleagues, was a respected and popular teacher at the Law School for five decades, and after that, at the New York Law School. He nurtured generations of statesmen, judges, academics, and practicing lawyers.

President Bill Clinton, a 1973 graduate of Yale Law School and a former student of Professor McDougal, expressed sadness in a letter to the McDougal family and friends. Clinton wrote: "Mac was a central part of the Yale Law School community. His conception of the ultimate goal of law as the achievement of human dignity, and his insistence that each legal application be appraised in terms of its contribution to that dignity, inspired many of us to dedicate our lives to public service and will continue to guide our efforts."

Yale trustee Judge José A. Cabranes, another of Professor McDougal's former pupils, noted: "Mac's scholarship and his advocacy has touched most of the great foreign policy debates of our time: United States participation in the new, post-war order; the principles of law governing the exercise of coercive authority by great powers in that new order; the international protection of human rights (a subject that Mac helped to place on the map, and which he introduced to law school curricula); the use of executive agreements in the conduct of our foreign affairs; the application of international law by United States tribunals; the law of the sea; and the law of outer space (an interest of his that some of us in 1962 regarded, quite incorrectly, as eccentric).... Myres McDougal was, without a doubt, the greatest international lawyer of his time."

Professor McDougal was born in 1906 in Burton, Mississippi. He received a B.A., M.A. and LL.B. degrees from the University of Mississippi and was a Rhodes Scholar at Oxford, where he received a B.C.L. in 1930. At Oxford, he was a student of the legal historian Sir William Holdsworth, who had a profound influence on his later work. Although invited to teach at Oxford, Mr. McDougal returned to the United States to earn his doctorate in 1931 from the Yale Law School.

After a brief teaching stint at the University of Illinois, he returned to Yale in 1934. Working in the area of property law, he was the first scholar to reconceive this traditional body of law in terms of comprehensive resource planning.

During World War II, Professor McDougal took a leave from Yale to serve his country, first as assistant general counsel of the Lend-Lease Administration (1942); then as general counsel of the State Department's Office of Foreign Relief and Rehabilitation Operations (1943).

Professor McDougal turned his attention after the war to international law, and it was in this area that he made his best-known contributions. He produced, in collaboration with his students, six major treatises on international issues, including the law of the sea, the law of outer space, the law of war, and the law of human rights. In 1943, he and Lasswell published their first joint endeavor, "Legal Education and Public Policy," a fundamental and path-breaking work in its field.

Among his other positions, he served as president of the American Society of International Law in 1958, and was president of the Association of American Law Schools in 1966.

Professor McDougal is survived by his wife of more than 60 years, the former Frances Lee, and a son, John Lee McDougal.

Adapted from the Yale Bulletin \& Calendar

\section{Mancur Olson}

The sudden passing of Mancur Olson on February 19, 1998, at the age of 66 , was a blow to his many colleagues, admirers, and friends. Rarely, if ever, has one individual made such a notable difference to political science. His intellectual audacity was ever a trade mark of his style and always on display, as in the opening of his second volume, The Logic of Collective Action:

Since most (though by no means all) of the action taken by or on behalf of groups of individuals is taken through organizations, it will be helpful to consider organizations in a general or theoretical way.

This work, which identified the conflict between individual rational choice and the imperatives of action to support group goals, changed the way the world of political science thought of political behavior, political organizing, and the output of governments. (In 1993, the American Academy of Management awarded it a Best Book Award, for its enduring contributions to our understanding of society.) The contribution stemmed from Mancur's singular focus on the big questions of social science. He described this predilection nicely in a communication to Avinash Dixit in July 1997: 